\title{
Extremophiles in Soil Communities of Former Copper Mining Sites of the East Harz Region (Germany) Reflected by Re-Analyzed 16S rRNA Data
}

\author{
J. Michael Köhler*(D, Nancy Beetz, Peter Mike Günther, Frances Möller and Jialan Cao $(D)$
}

check for updates

Citation: Köhler, J.M.; Beetz, N.; Günther, P.M.; Möller, F.; Cao, J. Extremophiles in Soil Communities of Former Copper Mining Sites of the East Harz Region (Germany) Reflected by Re-Analyzed 16S rRNA Data. Microorganisms 2021, 9, 1422. https://doi.org/10.3390/ microorganisms 9071422

Academic Editors: Ricardo Amils, Annarita Poli and Ilaria Finore

Received: 26 February 2021

Accepted: 25 June 2021

Published: 30 June 2021

Publisher's Note: MDPI stays neutral with regard to jurisdictional claims in published maps and institutional affiliations.

Copyright: (c) 2021 by the authors. Licensee MDPI, Basel, Switzerland. This article is an open access article distributed under the terms and conditions of the Creative Commons Attribution (CC BY) license (https:/ / creativecommons.org/licenses/by/ $4.0 /)$.
Department of Physical Chemistry and Microreaction Technology, Institute for Micro and Nanotechnologies/Institute for Chemistry and Biotechnology, Technical University Ilmenau, 98693 Ilmenau, Germany; nancy.beetz@tu-ilmenau.de (N.B.); mike.guenther@tu-ilmenau.de (P.M.G.); frances.moeller@tu-ilmenau.de (F.M.); jialan.cao@tu-ilmenau.de (J.C.)

* Correspondence: michael.koehler@tu-ilmenau.de

\begin{abstract}
The east and southeast rim of Harz mountains (Germany) are marked by a high density of former copper mining places dating back from the late 20th century to the middle age. A set of 18 soil samples from pre- and early industrial mining places and one sample from an industrial mine dump have been selected for investigation by $16 \mathrm{~S}$ rRNA and compared with six samples from non-mining areas. Although most of the soil samples from the old mines show $\mathrm{pH}$ values around 7, RNA profiling reflects many operational taxonomical units (OTUs) belonging to acidophilic genera. For some of these OTUs, similarities were found with their abundances in the comparative samples, while others show significant differences. In addition to $\mathrm{pH}$-dependent bacteria, thermophilic, psychrophilic, and halophilic types were observed. Among these OTUs, several DNA sequences are related to bacteria which are reported to show the ability to metabolize special substrates. Some OTUs absent in comparative samples from limestone substrates, among them Thaumarchaeota were present in the soil group from ancient mines with $\mathrm{pH}>7$. In contrast, acidophilic types have been found in a sample from a copper slag deposit, e.g., the polymer degrading bacterium Granulicella and Acidicaldus, which is thermophilic, too. Soil samples of the group of pre-industrial mines supplied some less abundant, interesting OTUs as the polymer-degrading Povalibacter and the halophilic Lewinella and Halobacteriovorax. A particularly high number of bacteria (OTUs) which had not been detected in other samples were found at an industrial copper mine dump, among them many halophilic and psychrophilic types. In summary, the results show that soil samples from the ancient copper mining places contain soil bacterial communities that could be a promising source in the search for microorganisms with valuable metabolic capabilities.
\end{abstract}

Keywords: soil bacteria; ancient mining places; halophiles; acidophiles; thermophiles; psychrophiles; NGS

\section{Introduction}

Microbial diversity is very important for a healthy environment and for fertile soils [1,2]. Besides ubiquitous bacteria, less abundant types also contribute to the diversity in soil bacterial communities [3,4]. Among them, extremophilic bacteria can also be found. It is well known that the acid drainage of active mines causes the development of acidophilic bacterial communities, which are of interest for bioleaching [5,6]. However, many microbial types related to lower $\mathrm{pH}$ are also found in many other and in non-acidic soils. Many families and genera of Acidobacteria, for example, are very abundant and interesting for usable bioproducts, but the investigation of their physiology and ecology is hindered by difficulties in cultivation $[7,8]$.

The special ecological situation and the prevalence of acidophilic bacteria in industrial mining areas can easily be explained by the acidification due to bioleaching and 
biooxidation of minerals. In contrast, ancient mining areas usually show a special pattern of vegetation and soil development, although former mining activities ceased centuries ago [9]. Obviously, their soils and soil microbial communities represent a typical example of ecological memory. Traces of early human activities, which changed the structure and character of soils, can be stored over a long time and are reflected in the local compositions of the soil bacterial communities. This "ecological memory of soil" was observed, for example, on prehistorical settlements, working and burial places [10-13]. The understanding of "man-made environments", mining-related acidic soils among them, for example, remains an urgent challenge for investigations of soil microbial communities up to now [14].

An ecological memory effect could also be observed on ancient mining sites of the East Harz copper mining region (Sachsen-Anhalt, Germany) $[15,16]$. The metal mining in this region dates back to the Middle Ages but continued up to the 1990s [9]. As expected, the abundance of different bacterial types is strongly dependent on $\mathrm{pH}$, which was confirmed by comparing some of these East Harz mining places with other soil samples from Central Germany. Besides acidophilic and halophilic types, the ancient mining places also yielded bacterial DNA of thermophilic taxonomical units. During an investigation of soil bacterial communities of a group of mining and smelting places, special types of less-abundant extremophiles were found, among them Hadesarchaeota [15].

The abundance of special bacterial types, and of extremophiles in particular, is not only of interest for the biodiversity and robustness of the local ecological situation [17], the remediation of industrial used areas, and their sustainable usage. It is also very important for the search of microorganisms with special metabolic activities which could be applied in new biotechnological processes [18]. Therefore, here, 16S rRNA profiling data of soil samples from East Harz copper mining places are analyzed and partially re-analyzed for their possible relevance in searching for further interesting extremophiles. The soil samples were collected, originally, in searching for heavy metal-tolerant bacterial strains, but then found to be of interest with respect to halophilic, acidophilic, and thermophilic bacteria too [15].

\section{Materials and Methods}

\subsection{Soil Samples}

For the investigation, $16 \mathrm{~S}$ rRNA data of 18 soil samples from pre-industrial and early industrial copper mining places in the East Harz region have been selected. Six samples originate from deposits surrounding pre-industrial mine shafts (Wolferode, Wimmelburg, Wiederstedt, Hergisdorf), six samples are from deposits near early industrial mining shafts (Hettstedt and Welfesholz) and six samples are from deposits surrounding earlier mine shafts (Pölsfeld, Rodishain, and Uftrungen, approximately 15th/16th century). The sample material (No. 1-19) is not any kind of typical natural soil, but surface material from the mine dumps, was brought from the ground to the surface during the site-related mining phases. The soil material was taken during dry weather periods. For sampling vegetationfree spots of the surface have been used. The material was stored in sterile 50-mL sample tubes. The samples were dried at room temperature. The sampling locations, their GPS coordinates, $\mathrm{pH}$ values, and electrical conductivity values are given in Table 1 . In addition, a map showing the sampling sites is provided in the supplementary material.

The idea behind the selection of soil samples was to search for special bacterial types related to mining activities in the past and compare them with some samples from nonmining places. Thus, small mining places, in particular from the early mining activities in the 15th-18th century (Uftrungen, Rodishain, Pölsfeld, Hergisdorf, Wolferode and Wiederstedt), early industrial mining sites (1st half of 19th century; Burgörner, Hettstedt, Welfesholz) and two industrial places (20th century) were chosen. 
Table 1. Origin of samples (overview, for more details, please see supplementary material; Tables S1 and S2).

\begin{tabular}{|c|c|c|c|c|}
\hline No. & Location & Group & pH Value & Electrical Conductivity \\
\hline 1 & Wolferode, pre-industrial mine & A & 7.15 & $225 \mu \mathrm{S} / \mathrm{cm}$ \\
\hline 2 & Wolferode, pre-industrial mine & $\mathrm{B}$ & 7.56 & 220 \\
\hline 3 & Wimmelburg, slag deposit & $\mathrm{D}$ & 5.57 & 35.4 \\
\hline 4 & Hergisdorf, pre-industrial mine & A & 7.11 & 724 \\
\hline 5 & Wiederstedt, pre-industrial mine & $\mathrm{B}$ & 7.72 & 695 \\
\hline 6 & Wiederstedt, pre-industrial mine & $\mathrm{B}$ & 7.63 & 201 \\
\hline 7 & Welfesholz, mine dump, early 19 th century & $\mathrm{C}$ & 8.24 & 94.5 \\
\hline 8 & Welfesholz, mine dump, early 19 th century & $\mathrm{C}$ & 8.78 & 69.1 \\
\hline 9 & Burgörner, mine dump, early 19 th century & $\mathrm{C}$ & 8.27 & 148 \\
\hline 10 & Burgörner, mine dump, early 19th century & $\mathrm{C}$ & 8.85 & 82 \\
\hline 11 & Burgörner, mine dump, early 19th century & $\mathrm{C}$ & 8.28 & 163 \\
\hline 12 & Burgörner, mine dump, early 19th century & $\mathrm{C}$ & 8.01 & 237 \\
\hline 13 & Pölsfeld, pre-industrial mine dump & $\mathrm{B}$ & 7.69 & 228 \\
\hline 14 & Rodishain, pre-industrial mine & A & 6.98 & 331 \\
\hline 15 & Rodishain, pre-industrial mine & A & 7.04 & 1240 \\
\hline 16 & Uftrungen, pre-industrial mine & A & 6.23 & 229 \\
\hline 17 & Uftrungen, pre-industrial mine & $\mathrm{A}$ & 6.79 & 367 \\
\hline 18 & Uftrungen, pre-industrial mine & A & 7.34 & 344 \\
\hline 19 & Nienstedt, industrial mine dump & E & 7.66 & 4677 \\
\hline \multicolumn{5}{|c|}{ Comparative sites (limestone substrate, forest) } \\
\hline 20 & Burgwenden, Monraburg, prehist. rampart & $\mathrm{F}$ & 7.84 & 183 \\
\hline 21 & Haynrode, Hasenburg, prehist. rampart, castle & $\mathrm{F}$ & 7.82 & 246 \\
\hline 22 & Kahla, Dohlenstein, prehist. rampart & $\mathrm{F}$ & 6.82 & 455 \\
\hline \multicolumn{5}{|c|}{ Comparative sites (acid soil, forest) } \\
\hline 23 & Suhl, Lange Bahn & G & 3.99 & 56.7 \\
\hline 24 & Völkershausen, Dietrich & G & 4.01 & 231 \\
\hline 25 & Rastenberg, Streitholz & G & 4.42 & 64.7 \\
\hline
\end{tabular}

In addition to the soil samples from ancient mining areas, one special soil sample was included which had been collected at the deposit pile base of the industrial copper mine of Nienstedt near Sangerhausen (Southeast Harz region, No. 19). Beside this sample, six other samples are included as comparative samples (control samples) which originate from forest-covered areas of ancient ramparts: three from limestone substrates (No. 20-22) and three from acid mineral substrates (quartzite and sandstone, No. 23-25). The comparative samples were chosen from a sample collection of different parts of Thuringia in order to have different regions and different geological situations. The samples from line stone substrates $(\mathrm{pH}>7.5$ ) came from northwest Thuringia (Haynrode), North Thuringia (Burgwenden) and from the Saale valley (Kahla). The samples from acid substrate soils were taken from southwest Thuringia (Northern Rhön, Völkershausen, basalt), South Thurigina (Suhl, sandstone), and Northeast Thurigina (Rastenberg, sandstone).

\subsection{DNA Extraction and Sequencing}

For DNA isolation, the Power Soil Isolation Kit (MO BIO, Carlsbad, CA, USA) was applied according to the protocol of supplier. The polymerase chain reactions (PCR) were carried out using an Edvocycler (Edvotek, Washington, DC, USA). Gel electrophoresis in $1.2 \%$ agarose gels was used for checking the success of each PCR amplification step. AMPure XP Beads (Beckman Coulter, Brea, CA, USA) were applied for the purification of the primary PCR products as well as for the completed pooled libraries according to the manufacturer's protocol.

The required adaptor primers for Amplicon PCR A519F-Ad (5' TCGTCGGCAGCGTC AGATGTGTATAAGAGACAGCAGCMGCCGCGGTAA $\left.3^{\prime}\right)$ and Bact_805R-Ad (5'-GTCTC GTGGGCTCGGAGATGTGTATAAGAGACAGGACTACHVGGGTATCTAATC 3’) were supplied by Eurofins Genomics (Ebersberg, Germany). A concentration of $100 \mathrm{pmol} / \mu \mathrm{L}$ was applied. The reaction mixtures (total volume of $50 \mu \mathrm{L}$ per reaction) were composed by 
following components: $1 \mu \mathrm{L}$ of DNA isolation eluate, $2 \mathrm{mM} \mathrm{MgCl}_{2}, 200 \mu \mathrm{M}$ PCR nucleotide mix, 1.25 Units GoTaq G2 Flexi DNA Polymerase, nuclease-free water (all reagents from Promega, Madison, WI, USA), and $1 \mathrm{pmol} / \mu \mathrm{L}$ of each primer. For PCR amplification, following program settings were used: start denaturation: $5 \mathrm{~min}$ at $94{ }^{\circ} \mathrm{C} ; 30$ amplification cycles involving $30 \mathrm{~s}$ denaturation at $94^{\circ} \mathrm{C}, 30 \mathrm{~s}$ annealing at $50{ }^{\circ} \mathrm{C}$ and $30 \mathrm{~s}$ primer extension at $72{ }^{\circ} \mathrm{C}$. The temperature cycling was finished with a final extension at $72{ }^{\circ} \mathrm{C}$ for $5 \mathrm{~min}$.

The required eight forward indexing primers and twelve reverse indexing primers for index PCR were delivered by integrated DNA technologies (Coralville, CA, USA). The primers were applied in a concentration of $1.25 \mathrm{pmol} / \mu \mathrm{L}$. The following composition was used for the index PCR: total volume of $25 \mu \mathrm{L}$ per reaction; $2.5 \mu \mathrm{L}$ of Amplicon PCR product, $2.5 \mathrm{mM} \mathrm{MgCl}$, $300 \mu \mathrm{M}$ PCR nucleotide mix, 0.5 Units GoTaq G2 Flexi DNA Polymerase, nuclease-free water (all reagents from Promega, Madison, WI, USA), and $125 \mathrm{nmol} / \mathrm{L}$ of each of the two primers of the respective indexing primer combination.

For index primer PCR, following program settings were applied: start denaturation: $3 \mathrm{~min}$ at $95^{\circ} \mathrm{C} ; 30$ amplification cycles involving $30 \mathrm{~s}$ denaturation at $95^{\circ} \mathrm{C}, 30 \mathrm{~s}$ annealing at $55^{\circ} \mathrm{C}$, and $30 \mathrm{~s}$ primer extension at $72{ }^{\circ} \mathrm{C}$. The temperature cycling was finished with a final extension at $72{ }^{\circ} \mathrm{C}$ for $5 \mathrm{~min}$.

The sequencing was done by GATC Biotech (Konstanz, Germany) and Eurofins (Ebersberg, Germany) by next generation sequencing on an Illumina HiSeq.

\subsection{Processing of NGS Data}

The software tool "Galaxy" [19] was applied for checking the quality of the NGS sequence data. All investigated data sets are characterized by a high median quality score.

The data processing was based on the automatic software pipeline of the SILVAngs data analysis service. It allowed a detailed community analysis sequencing data [20,21]. All data files from the NGS analyses were first converted from fastq file format to fasta file format by use of the fastq-to-fasta converter tool "phred33 conversion" (MR DNA Lab). The reads are aligned by SILVA Incremental Aligner (SINA SINA v1.2.10 for ARB SVN (revision 21008)) against the SILVA SSU rRNA SEED and quality controlled (applying minimal identity criteria of $98 \%$ ). Reads with a low alignment quality, less than 50 aligned nucleotides and reads with more than $2 \%$ of ambiguities, or $2 \%$ of homopolymers, respectively, were not processed. For classification, a BLAST search with the database SILVA Ref (release 132) was applied. For all analyses, the preset parameter sets of the settings page and with the SILVAngs database release version 132 were applied [21].

In many cases, the data from sequencing allow an assignment of bacterial groups down to the genus level. In some other cases, it is only possible to identify higher taxonomic levels. The lowest level identified is referenced as "operational taxonomic unit" (OTU). The comparison of soil bacteria and the compositions of microbial communities is based on the genera as far as possible or on OTUs. PCA was performed by using the Matlab standard procedure.

\section{Results and Discussion}

\subsection{Phyla and Dominant Taxonomical Units}

The phyla Proteobacteria, Planctomycetes, Bacteroidetes, Chloroflexi and Actinobacteria are abundant in all investigated samples. Besides, Verrucomicrobia, Gemmatimonadetes, Acidobacteria, and Archaea are abundant in most samples. However, the ratios of phyla vary significantly between the different samples (Figure 1a). The comparative samples from limestone substrates (No. 20-22) show significantly higher contents of Bacteroidetes than the comparative samples from the acidic soil substrates (No. 23-25). In contrast, the samples 23 and 24 ( $\mathrm{pH} 4.0)$ show an enhanced content of Acidobacteria.

The most marked differences in comparison with all other samples are observed for sample No. 19 (from the industrial copper mine deposit). It is characterised by a strong dominance of Bacteroidetes and very low contents of Acidobacteria and Archaea. 
In difference to the other samples, No. 3 is marked by a particularly high dominance of Chloroflexi.
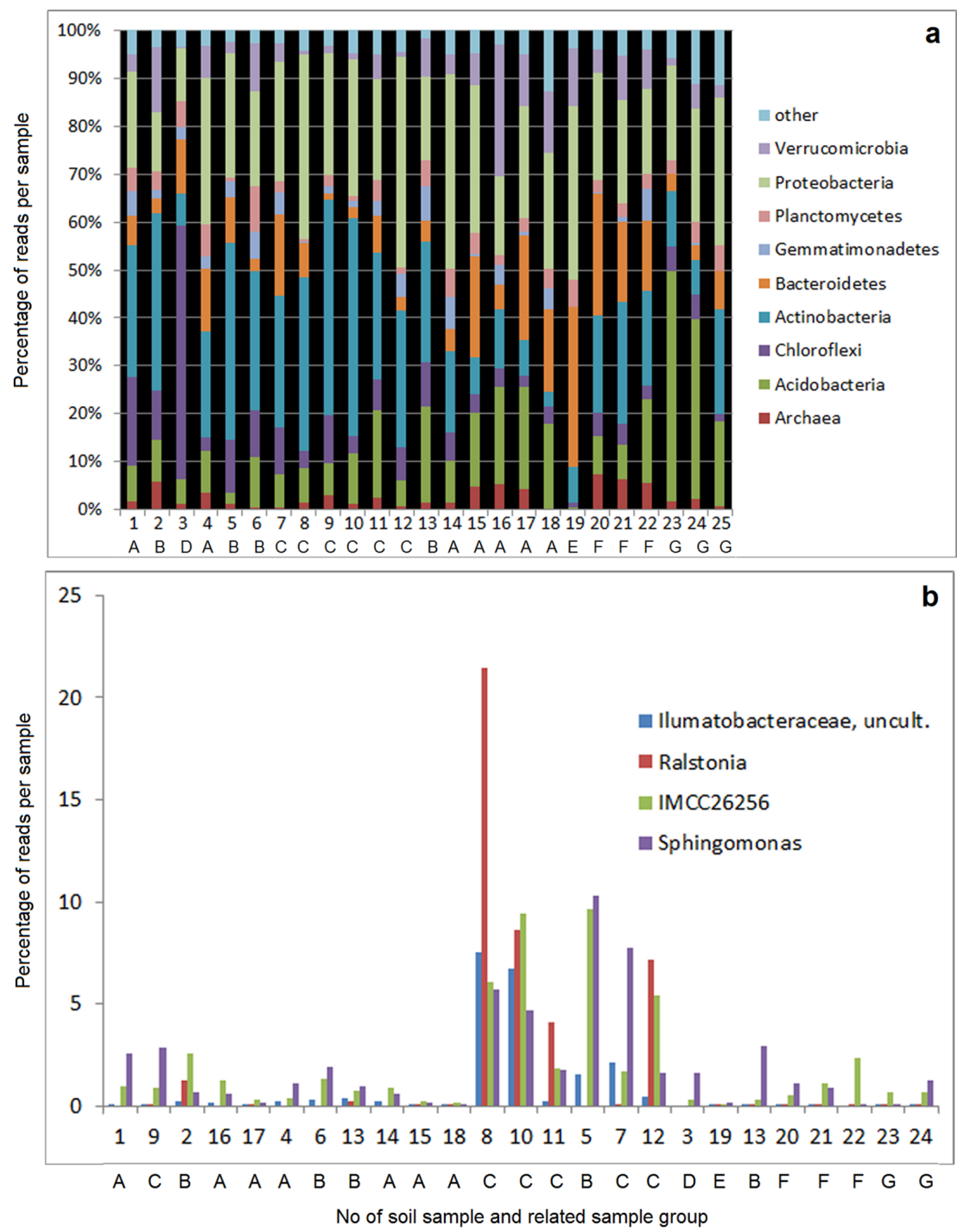

Figure 1. (a) Percentage of the most abundant phyla in the 19 investigated samples from formerly copper mining areas (No. 1-19, groups A-E) and the comparative samples (No. 20-25, groups F and G); (b) Domination of single OTUs: Percentages of the total number of reads for four single OTUs with high abundance in the samples 5 (Wiederstedt, group B, pH 7.72), 7 (Welfesholz, group C, pH 8.24), 8 (Welfesholz, group C, pH 8.78), 10 (Burgörner, group C, pH 8.85), 11 (Burgörner, group C, pH 8.28) and 12 (Hettstedt, group $\mathrm{C}, \mathrm{pH} 8.01$ ).

A clear differentiation of samples is possible by the abundance at a lower taxonomical level (Figure 1b). Particularly high contents in the group of four frequent OTUs (Sphingomonas, IMCC26256, Ralstonia and Ilumatobacteraceaea) are observed in the samples No. 5, 7, 8, and 10-12 (belonging mainly to sample group C), which differ from all other samples by these types (Figure 1b). This difference between samples seems to be related to some extent to the $\mathrm{pH}$ of the soil, because the samples No. 7-12 (all group C) showed the highest $\mathrm{pH}$ values (see Table 1). However, it should be noted that the samples No. 9 is not included in this group, despite its $\mathrm{pH}$ is also above 8. The abundances of Sphingomonas in some samples could be of special interest because their metabolic potential is important for the whole community, for example by production of phytohormones as gibberellines and indol acetic acid [22], which might also be interesting for the future improvement of soil fertility and remediation by means of biotechnological products. The bacterial 
communities of some of the other samples are dominated by one or a few abundant OTUs (see Supplementary Table S3). For example, sample 16 supplied in $26 \%$ of the reads the OTU Candidatus Ud. (Chthoniobacteraceae) and sample 3 supplied in $36 \%$ of reads two OTUs of Ktedonobacteraceae. From this table, it can be seen clearly, that the samples No. 5, $7,8,10,11,12$ (mostly group C) are distinguished from the other samples, which are closer related to the comparative samples from limestone substrates (Group F). Supplementary Table S3 also clearly shows the special situation of samples 3 and 19.

A comparison between the sample groups (A-G) was based on a logarithmic abundance parameter $r$ defined from the ratio of reads per OTU $\left(N_{i}\right)$ to the total of reads $N_{t o t}$ per sample:

$$
r=\log (1+1,000,000 * N i / N \text { tot })
$$

Principle component analyses (PCA) of sets of most frequent OTUs using this parameter $r$ reflect significant differences between the sample groups. The strength of distinguishing these groups depends on the set of included OTUs (Figure 2). The samples No. 3 (industrial slag deposit) and 9 (industrial mine dump) are clearly separated from the other samples if the 100 most abundant OTUs are considered (Figure 2a). No. 3 is also clearly separated from the others if the 20 most abundant OTUs are regarded (Figure 2b). Group $\mathrm{B}$ (pre-industrial mines, $\mathrm{pH}>7.5$ ) shows close relation to the comparative sample group F (limestone substrates) as could be expected. The comparative sample group from acid substrates $(G)$ is always well separated from the other groups.
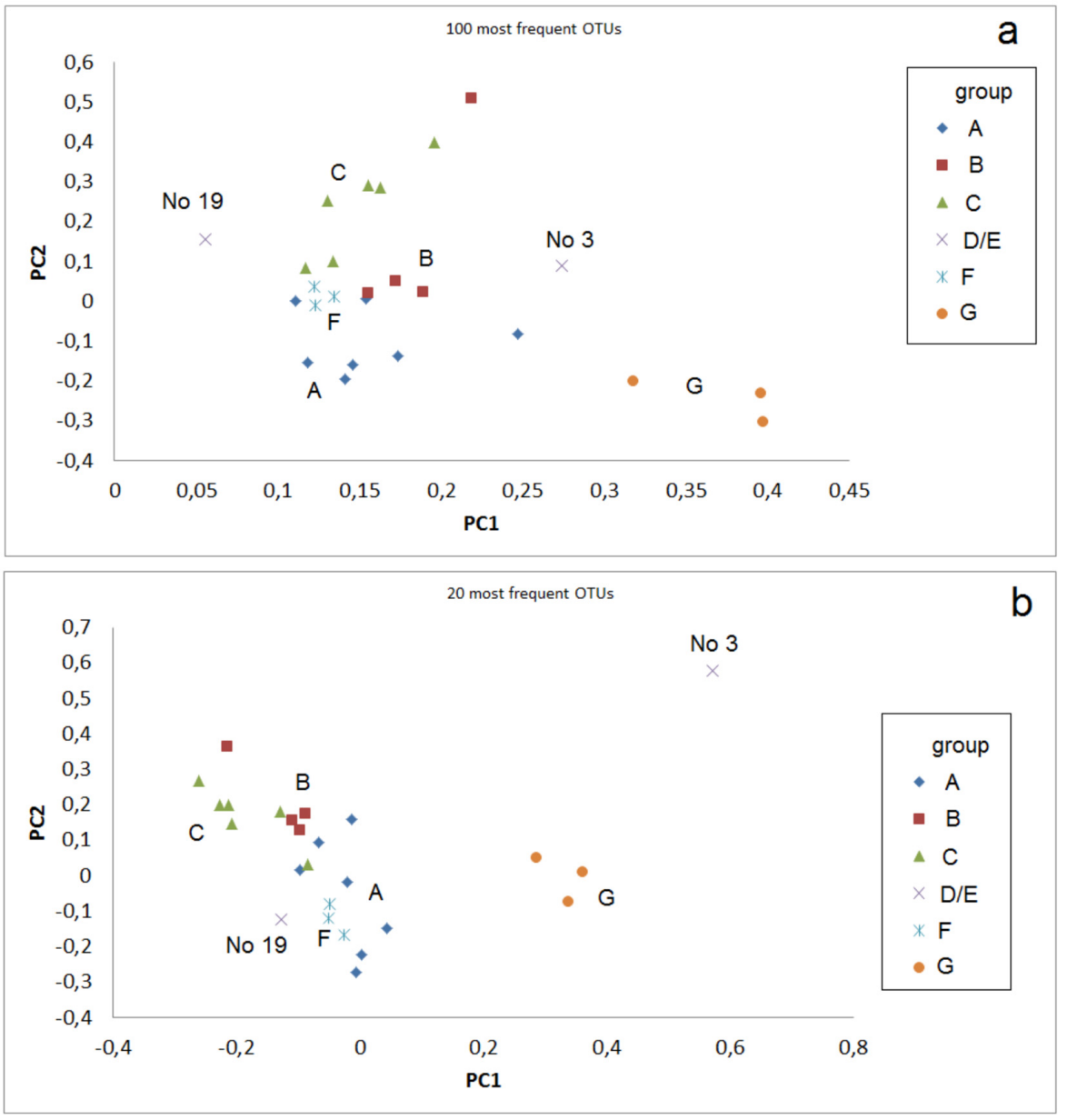

Figure 2. Principle component analysis of abundances in the sample groups by r-values (Equation (1)): (a) Principal component (PC) plot for PC1 and PC2 for the 100 most abundant OTUs; (b) Principal component plot for PC1 and PC2 for the 20 most abundant OTUs. 
A distinguishing of the groups $(A-G)$ is also possible by using sets of selected OTUs. The PCA including abundances of 17 OTUs shows two separate clusters of group F and four samples of group $C$. The other communities are found in a larger third cluster, but with a certain separation between Groups A, B, F, but including two samples of group C, too (Figure 3a). A better separation of sample group A from the other groups succeeded by correlation of r-values for selected OTUs, e.g., Kineosporiae, uncult., and Parafilimonas (Figure $3 \mathrm{~b}$ ). Group 3 can be distinguished from groups A, F, and G in the correlation plot of Ralstonia and Acidobacteria, Subgroup 2 (Figure 4a). Groups A and B are also well distinguishable by the correlation plot of Hyphomonadaceae SWB02 and Terrimonas (Figure 4b).
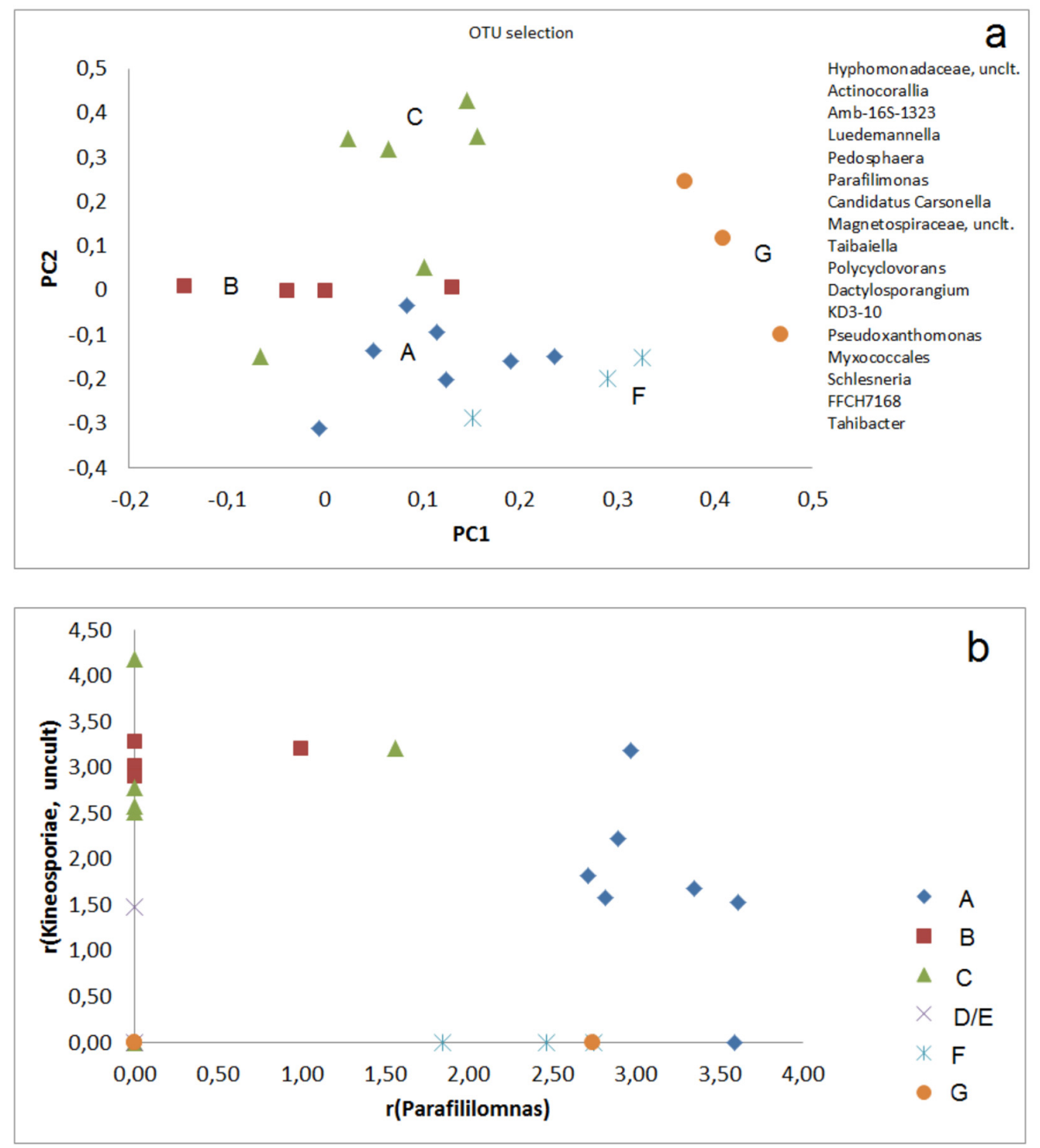

Figure 3. Distinguishing of sample groups by r-values (Equation (1)) of selected OTUs: (a) PCA of 17 selected OTUs; (b) Correlation of two selected OTUs (Parafilimonas, Kineosporiae). 

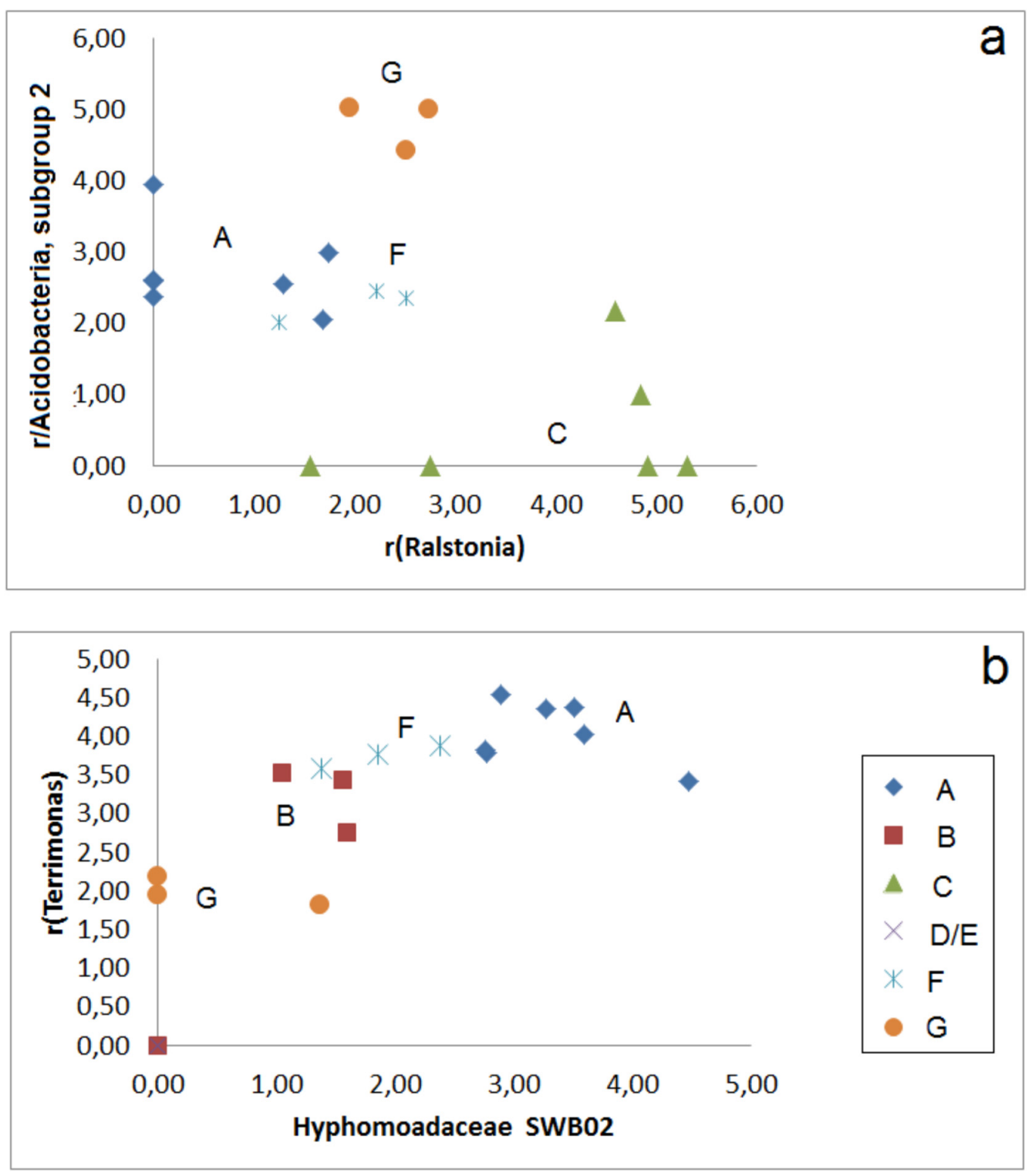

Figure 4. Correlation plots for abundance-related r-values for two pairs of selected OTUs: (a) Ralstonia/Acidobacteria, subgroup 2; (b) Hyphomonadaceae SWB02, Terrimonas.

\subsection{Abundances of Taxonomical Groups Related to Extremophilic Characters}

3.2.1. Acidobacteria, Acidimicrobiia and Other Actinobacteria

The bacteria of phylum Acidobacteria and the class Acidimicrobiia are of interest because many acidophilic species are found in these groups. In our case, the abundances of bacteria of these groups over the samples from the mining areas and the comparative samples do not reflect a clear relation to sample $\mathrm{pH}$ (Figure 5). Beyond this general point of view, considerable differences between the samples are evident. The most remarkable is the very low Acidobacteria content in sample 19. 

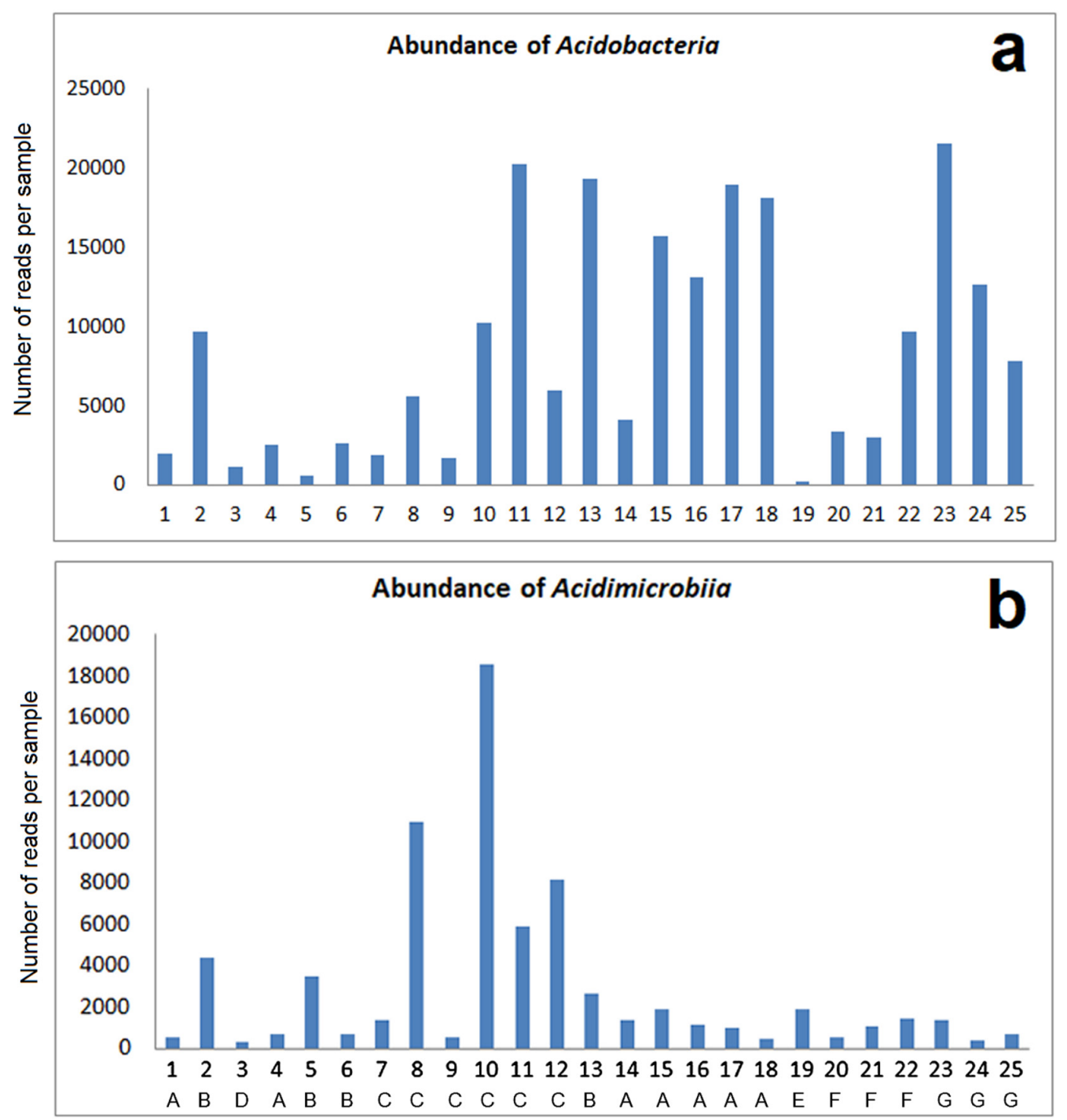

No of soil sample and related sample group

Figure 5. Highly abundant taxonomic groups (total number of reads per sample): (a) Acidobacteria; (b) Acidimicrobiia; The numbers on the $x$-axis are related to the sample numbers of Table 1.

Clearer differences as in the absolute number of reads for Acidobacteria in relation to the origin of soil samples were observed for the abundance of different orders and related lower taxonomic levels of this phylum. This distribution is shown for a selection of 10 of the investigated samples (Supplementary Figure S2): The comparative samples from acid soil (No. 24 and 25) are dominated by Acidobacteriales in combination with a high content of Solibacterales and very low contents of Blastocatellales and Acidobacteria Subgroup 6 , which are abundant in most of the other samples. The large part of other types in these samples is mainly related to Acidobacteria Subgroup2. A considerably high proportion of this group was also found in sample 19 (industrial mine dump, Nienstedt). The other samples (without sample 3) are marked by a common dominance of Blastocatellales and Subgroup 6 with Acidobacteriales. This picture matches the slightly higher $\mathrm{pH}$ of these samples.

The general abundances of Actinobacteria and Chloroflexi also varied between the samples, but without significant correlation with soil $\mathrm{pH}$ or conductivity (Figure 6). However, in analogy to the Acidobacteria, remarkable differences could be found at a lower taxonomic level (Supplementary Figure S3). Thus, sample 19 is very strongly dominated by a group of uncultivated Actinomarinales. In contrast to all other samples, the group IMCC26256 is less abundant in the bacterial community of this sample. The last-mentioned group, together 
with an uncultivated group of Acidimicrobia, dominates the comparative samples from acid soil. These samples show very low contents of uncultivated Ilumatobacteraceae as well as uncultivated Microtrichales, which is mostly in contrast to the other samples. There are some additional striking differences in the abundances of different types of Acidimicrobiia, among them the dominance of Iamia in sample 3 and the dominance of Ilumatobacteraceae in sample 8 and 10. While Iamia was isolated from sea cucumber [23], Ilumatobacter was found in estuary sediments [24], which is evidence of salt tolerance.
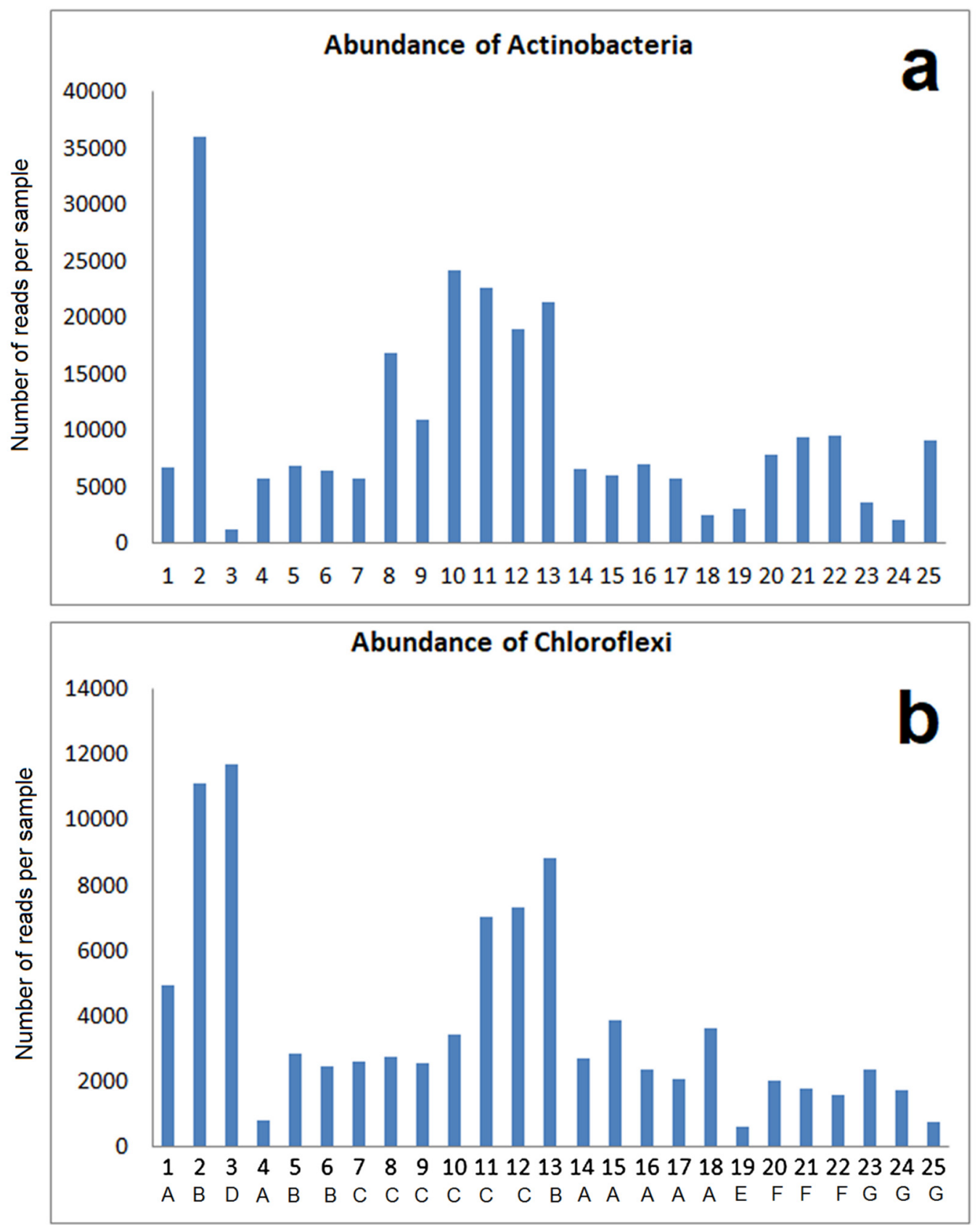

No of soil sample and related sample group

Figure 6. Highly abundant taxonomic groups (total number of reads per sample): (a) Actinobacteria; (b) Chloroflexi.

Besides Acidimicrobiia, the other classes of Actinobacteria reflect some typical differences, too (Supplementary Figure S4). The largest proportions of Corynebacteriales were found in sample 3 ( $\mathrm{pH}$ 5.57) and in the communities of comparative samples from acid 
soils (No. 24 and 25). Sample 3 and 19 are noted by a high content of Micrococcales. Both types are abundant in wet soils, in general, and are marked by a high GC content in the DNA.

\subsubsection{Abundances of Chloroflexi}

Despite the differences in the total abundance of Chloroflexi, the examples of soil samples from the ancient mining places as well as from the industrial mine dump (Supplementary Figure S5) reflect a high abundance of Ktedonobacteria. The samples 8, 10, and 11 ( $\mathrm{pH}$ values above 8) show significant proportions of the groups Gitt-GS-136 and KD4-96, which are also abundant in the comparative samples from limestone substrate, but less abundant in the samples 3, 16, and 19 as well as 24 and 25 (acid soil samples). The high content of "others" in the comparative samples from the acidic soil (Supplementary Figure S5) is mainly due to the group Chloroflexi AD3, which is less or not present in the other samples. Sample 3 only showed 100 reads of this group. This type was found earlier in acid mine drainage and represents obviously acidophilic strains of soil bacteria [25].

\subsubsection{Special $\mathrm{pH}$-Dependent OTUs}

There exist a number of OTUs which are moderately present in the majority of the samples from ancient mining areas (without sample 3) and in all comparative samples from limestone areas (No. 20-22), but completely absent in the acid comparative samples (No. 23-25) This characteristic non-acidophilic behaviour was found in the investigated bacterial communities, e.g., for Longimicrobiaceae, for Chloroflexi group P2-11E, for the Planctomycetes group OM190, for the Sphingobacteriales KD3-93, for Kribella, and for the Chloroflexi group OLB14, with slightly reduced abundance for Lysobacter and the groups SM1A02 and NS11-12 marine groups (Supplementary Figure S6).

The opposite situation is observed with a group involving Acidipilia, Edaphobacter, Granulicella, an acidophilic polymer degrading bacterium, Actinospica, Acidicaldus, and Roseiarcus, which are more abundant in the communities from the acidic comparative samples and partially in sample 3 (Supplementary Figure S7). Some further OTUs (AAP99, JG36-TzT-191, Thaumarchaeota 1.1c) are absent in the comparative samples from limestone soil (No. 20-22) but appear on some ancient mining areas which show a soil pH between 6 and 7. Edaphobacter was isolated from forest soil and described as adapted to a neutral to slightly acidic environmental situation. Five strains of Granulicella were found to be adapted for acidic conditions ( $\mathrm{pH}$ optimum at 3.8-4.0). In addition, they are psychrotolerant (2$33^{\circ} \mathrm{C}$ ) and show hydrolysis capability for pectin, xylan, laminarin, lichenan, and starch [26]. Actinospica was isolated from forest soil and characterized as an acidophilic bacterium [27]. Acidicaldus was isolated acidophilic (growing fast between pH 2.5 and 3) and thermophilic (optimum between 50 and $55{ }^{\circ} \mathrm{C}$ [28]. Roseiarcus was isolated from a methanotrophic microorganism consortium and showed a slightly acidophilic characteristic [29].

3.2.4. Halo- and Psychrophilic Bacterial Soil Community in a Sample from Industrial Mine Dump Nienstedt

Sample No. 19 has a special position between the soil samples of the ancient mining areas (No. 1-18) and the comparative samples (20-25). In contrast to the ancient shaft hole places and small mine dumps, the base area of the industrial mine dump has no vegetation and nearly no humus formation. The sample is marked by a moderate $\mathrm{pH}(7.66)$ but has a very high electrical conductivity compared to all other samples, indicating a high concentration of mobile ions. This situation is clearly reflected by strong differences in the composition of the soil bacterial community. In sample 19, many OTUs were found with mediate or high read numbers, which are very rare or completely absent in all other samples (see Supplementary Table S4). The special soil communities of this sampling site could be explained by the special situation of this place. On the one hand, this large mine dump was operated in the 20th century and has been closed for some decades. This is in strong contrast to the small mines and dumps from the early industrial and the preindustrial era, which have not operated in several centuries. The place (No. 19) has nearly 
no vegetation and therefore it was surprising to see the large spectrum of different OTUs in the NGS data. In addition, this place showed the highest electrical conductivity of soil speaking for a high content of soluble salts. This fact explains the high content of halophilic types, but in addition, evinces another character of the microbial community as whole.

It is less surprising that many salt-tolerant or halophilic bacteria are in the abovementioned group of microorganisms. This group involves mostly bacteria firstly described from sea water or marine environments, in general, among them the genera Salinisphaera [30], Marinimicrobium [31], Marinoscillum [32], Roseivirga [33], Arenibacter [34], Cellulophaga [35], Confluentibacter [36], Gaetbulibacter [37], Maribacter [38], Muricauda [39], Tamlana [40], Balneola [41], Jannaschia [42], and Hoeflea (formerly "Agrobacterium") [43]. For Muricauda, it is noteworthy that it can use hexadecane as the sole carbon source [39].

More interestingly, the special group of bacteria from the industrial mine dump involves a considerable portion of psychrophilic bacteria firstly isolated from artic environments. These include the genera Loktanella [44], Pricia [45], Cryomorpha [46], and Algibacter [47]. In addition, there are several OTUs related to genera with pigment producing strains, for example, belonging to Aequorivita [48], Salegentibacter [49], Subsaxibacter [50], and Arcticiflavibacter [51]. It is important to mention that the majority of these found genera are represented in the investigated sample in a comparatively high number of reads. A noticeably high number of reads (626) was also found for Psychroflexus, which is famous for its special ability to produce eicosanopentaeonic acid, a polyunsaturated fatty acid [52]. Despite the occurrence of a lot of halophilic organisms in this sample, the content of psychrophilic genera confirms the special character of the related soil bacterial community. The coincidence of salt content, appearance of psychrophiles, and high probability of temporary exposure to heavy metals from the dump erosion support the formation of soil microbiomes of special compositions containing types, from which special metabolic features could be expected, e.g., related to metalloenzymes.

\subsubsection{Less Abundant Types with Special Tolerances and Metabolic Features}

The NGS data reflect a set of less abundant further OTUs besides the taxonomic groups mentioned above, which are of interest due to their special tolerance features and promising physiological activities. An overview is presented in Supplementary Table S5. These OTUs are not "rare types" and most of them are also found in low read numbers in the group of comparative samples. Included are OTUs with these special properties described in the literature, which occur in at least 10 reads in total over all samples. Among them are thermophilic bacteria, such as Tepidiphilus, Anaerolinea, and Alterococcus, as well as salt-tolerant bacteria, such as Fulvivirga, Tistlia, Lewinella, Marisediminicola, Salinispora, and Halobacteriovorax. Several of these types have been reported to be able to degrade special substances, for example agar, gellan-gum, salicylate, molinate, alkanes, synthetic polymers like polyvinylalcohol and critical environmentally hazardous substances like aromatic and polycyclic hydrocarbons (Supplementary Table S5). The special types have different occurrence in the sample groups. Thus, the polyvinylalcohol-degrading Povalibacter, the halophilic bacteria Lewinella and Halobacteriovorax were found in group A (pre-industrial mines), whereas polymer-degrading acidophilic organisms among them Thaumarchaeota appeared in the soil of the slag deposit area (group D).

\section{Conclusions}

The analysis of the $16 \mathrm{~S}$ rRNA data from the former copper mining places of the East Harz region reflects the occurrence of different groups of extremophilic bacteria, including acidophiles, halophiles, as well as thermophiles. Even the mining sites operated in the pre-industrial period (about 16th to 18th century) and the early industrial period (first half of 19th century) supplied bacterial types that differ in their occurrence or abundance from six selected comparative samples from non-mining sites. The occurrence of some taxonomic groups of acidophilic bacteria correlates with comparative samples from forest areas on acidophilic substrates, while others differ significantly from them. A considerably 
high portion of salt-tolerant, halophilic, as well as psychrophilic bacteria was exclusively found in a sample from the base of an industrial mine dump operated in the 20th century.

Among the identified genera, there are some that have been reported to have special metabolic features. This concerns the ability to metabolize various macromolecular carbohydrates as well as synthetic polymers, synthetic aromatic hydrocarbons, and polycyclic aromatic compounds. Some of the strains belonging to the genera found produce different types of pigments or other special metabolites, or a polyunsaturated fatty acid, for example. The differences in the composition of soil microbial communities and the abundances of genera known for extremophilic behavior are not related to soil $\mathrm{pH}$ exclusively and salt content. In addition, components of soil bacteria were found in the samples, indicating that different sampling sites can be valuable to the search for new strains with interesting metabolic properties.

It can be concluded that, besides the special situation in recently operated mines, mine dumps, and acid main draining, ancient mining sites with mining activities dating back over centuries could also be interesting places to find promising special soil bacterial communities, including extremophiles and bacterial strains with different tolerance features and interesting metabolic capabilities.

Supplementary Materials: The following are available online at https://www.mdpi.com/article/10 .3390 / microorganisms9071422/s1, Figure S1. Origin of samples ((C) GDI-Th); Figure S2. Distribution of abundant orders of Acidobacteria (percentages of orders in the class) in 5 selected samples from ancient mining areas (No. 3 Wimmelburg, slag deposit, $\mathrm{pH}$ 5.57), 8 (Welfesholz, group C, pH 8.78), 10 (Burgörner, group C, pH 8.85), 11 (Burgörner, group C, pH 8.28), 16 (Uftrungen, Group A, pH 6.23), from industrial mine dump (No. 19, Nienstedt, $\mathrm{pH} 7.66$, extraordinary high electrical conductivity) and four comparative samples (limestone substrate: No. 20 and 22 (group F), acid soil: No. 24, 25 (group G)); Figure S3. Distribution of abundant OTUs of Acidimicrobiia (percentage of classes in the phylum Actinobacteria) in 5 selected samples from ancient mining areas (No. 3 Wimmelburg, slag deposit, pH 5.57), 8 (Welfesholz, group C, pH 8.78), 10 (Burgörner, group C, pH 8.85), 11 (Burgörner, group C, pH 8.28), 16 (Uftrungen, Group A, pH 6.23), from industrial mine dump (No. 19 , Nienstedt, pH 7.66, extraordinary high electrical conductivity) and four comparative samples (limestone substrate: No. 20 and 22 (group F), acid soil: No. 24, 25 (group G)); Figure S4. Distribution of selected abundant orders of Actinobacteria (percentage of orders (without Acidimicrobiia) in the class) in 5 selected samples from ancient mining areas (No. 3 Wimmelburg, slag deposit, $\mathrm{pH}$ 5.57), 8 (Welfesholz, group $\mathrm{C}, \mathrm{pH}$ 8.78), 10 (Burgörner, group $\mathrm{C}, \mathrm{pH}$ 8.85), 11 (Burgörner, group $\mathrm{C}$, $\mathrm{pH}$ 8.28), 16 (Uftrungen, Group A, pH 6.23), from industrial mine dump (No. 19, Nienstedt, $\mathrm{pH}$ 7.66, extraordinary high electrical conductivity) and four comparative samples (limestone substrate: No. 20 and 22 (group F), acid soil: No. 24, 25 (group G)); Figure S5. Distribution of abundant OTUs of Chloroflexi (percentage in the class) in 5 selected samples from ancient mining areas (No. 3 Wimmelburg, slag deposit, pH 5.57), 8 (Welfesholz, group C, pH 8.78), 10 (Burgörner, group C, pH 8.85), 11 (Burgörner, group C, pH 8.28), 16 (Uftrungen, Group A, pH 6.23), from industrial mine dump (No. 19, Nienstedt, pH 7.66, extraordinary high electrical conductivity) and four comparative samples (limestone substrate: No. 20 and 22 (group F), acid soil: No. 24, 25 (group G); Figure S6. Abundances of nine selected OTUs on ancient mining sites, absent in the comparative samples from acidic Scheme 23-25, group G); Figure S7. Abundances of nine selected OTUs with acidophilic character and comparatively high representation in the comparative samples from acid soil (No. 23-25, group G); Table S1: Origin of sample, $\mathrm{pH}$ and electrical conductivity, Table S2: groups of samples; Table S3: Percentage of high abundant OTUs in the samples from formerly mining areas and comparative samples; Table S4: Special OTUs from an industrial copper mining deposit with high electrical conductance of soil material (No. 19, Nienstedt, sample H5), neither present in soil samples from ancient copper mining places (No. 1-18) nor in the comparative samples (No. 20-25); Table S5. Selected OTUs with special metabolic and tolerance features.

Author Contributions: Conceptualization, J.M.K. and J.C.; methodology, J.M.K., J.C., F.M., and N.B.; software and formal analysis, P.M.G.; experimental investigation, N.B., F.M., and J.M.K.; writingoriginal draft preparation, J.M.K. and J.C.; writing-review and editing, J.M.K., J.C., and P.M.G.; project administration, J.M.K. All authors have read and agreed to the published version of the manuscript. 
Funding: This research received no external funding.

Institutional Review Board Statement: Ethical review and approval were waived for this study, due to the fact that no animals have been used and soil samples from German territory only have been investigated.

Informed Consent Statement: Not applicable.

Data Availability Statement: The data presented in this study are available on request from the corresponding author.

Acknowledgments: The support of Steffen Schneider (Ilmenau) for data processing is gratefully acknowledged. We acknowledge support for the publication costs by the Open Access Publication Fund of the Technische Universität Ilmenau.

Conflicts of Interest: The authors declare no conflict of interest.

\section{References}

1. Torsvik, V.; Sorheim, R.; Gokskoyr, J. Total bacterial diversity in soil and sediment-A review. J. Indust. Microbiol. 1996, 17, 170-178. [CrossRef]

2. Bartelt-Ryser, J.; Joshi, J.; Schmid, B.; Brandl, H.; Balser, T. 2005 Soil feedbacks of plant diversity on soil microbial communities and subsequent plant growth. Persp. Plant Evol. Evol. Syst. 2005, 7, 27-49. [CrossRef]

3. Aanderud, Z.T.; Jones, S.E.; Fierer, N. Resuscitation of the rare biosphere contributes to pulses of ecosystem activity. Front. Microbiol. 2015, 6, 24. [CrossRef]

4. Jones, S.E.; Lennon, J.T. Dormancy contributes to the maintenance of microbial diversity. Proc. Natl. Acad. Sci. USA 2010, 107, 5881-5886. [CrossRef] [PubMed]

5. Hedrich, S.; Schippers, A. Metallgewinnung mittels Geobiotechnologie. Chem. Ing. Tech. 2017, 89, 29-39. [CrossRef]

6. Thavamani, P.; Samkumar, R.A.; Satheesh, V.; Subashchandrabose, S.R.; Ramadass, K.; Naidu, R.; Venkateswarlu, K.; Megharaj, M. Microbes from mined sites: Harnessing their potential for reclamation of derelicted mine sites. Environ. Pollut. 2017, 230, 495-505. [CrossRef]

7. Barns, S.M.; Cain, E.C.; Sommerville, L.; Kuske, C.R. Acidobacteria phylum sequences in uranium-contaminated subsurface sediments greatly expand the known diversity within the phylum. Appl. Environ. Microbiol. 2007, 73, 3113-3116. [CrossRef]

8. Lewis, K.; Epstein, S.; D’onofrio, A.; Ling, L.L. Uncultured microorganisms as a source of secondary metabolites. J. Antibiot. 2010, 63, 468-476. [CrossRef]

9. Clement, M. Tausend Jahre Metallerzbergbau in Mitteleuropa; VGE: Essen, Germany, 1996.

10. Margesin, R.; Siles, J.A.; Cajthaml, T.; Ohlinger, B.; Kistler, E. Microbiology meets archaeology: Soil microbial communities reveal different human activities at archaic Monte Iato (Sixth century BC). Microbial. Ecol. 2017, 73, 925-938. [CrossRef]

11. Köhler, J.M.; Kalensee, F.; Günther, P.M.; Schüler, T.; Cao, J. The local ecological memory of soil: Majority and minority components of bacterial communities in prehistoric urns from Schöps (Germany). Int. J. Environ. Res. 2018, 12, 575-684. [CrossRef]

12. Köhler, J.M.; Beetz, N.; Günther, P.M.; Möller, F.; Schüler, T.; Cao, J. Microbial community types and signature-like soil bacterial patterns from fortified prehistoric hills of Thuringia (Germany). Community Ecol. 2020, 21, 107-120. [CrossRef]

13. Chernysheva, E.; Korobov, D.; Borisov, A. Thermophilic microorganisms in arable land around medieval archaeological sites in Northern Caucasus, Russia: Novel evidence of past manuring practices. Geoarchaeol. Int. J. 2017, 32, 494-501. [CrossRef]

14. Hedrich, S.; Schippers, A. Distribution of acidophilic microorganisms in natural and man-made acidic environments. Curr. Issues Mol. Biol. 2021, 40, 25-47. [CrossRef]

15. Köhler, J.M.; Kalensee, F.; Cao, J.; Günther, P.M. Hadesarchaea and other extremophile bacteria from ancient mining areas of the East Harz region (Germany) suggest an ecological long-term memory of soil. SN Appl. Sci. 2019, 1, 839. [CrossRef]

16. Köhler, J.M.; Kalensee, F.; Günther, P.M.; Cao, J. Searching for Rare Type Associations in Bacterial Communities from Ancient Copper Mining Areas in the East Harz region (Germany). Asp. Min. Miner. Sci. 2018, 2, 1-14. [CrossRef]

17. Ratzke, C.; Barrere, J.; Gore, J. Strength of species interactions determines biodiversity and stability in microbial communities. Nat. Ecol. Evol. 2020, 4, 376. [CrossRef] [PubMed]

18. Purohit, J.; Chattopadhyay, A.; Teli, B. Metagenomic exploration of plastic degrading microbes for biotechnological applications. Curr. Genom. 2020, 21, 253-270. [CrossRef] [PubMed]

19. Gordon, A. Available online: http:/ / hannonlab.cshl.edu/fastx_toolkit (accessed on 28 June 2021).

20. Quast, C.; Pruesse, E.; Yilmaz, P.; Gerken, J.; Schweer, T.; Yarza, P.; Peplies, J.; Glockner, F.O. The SILVA ribosomal RNA gene database project: Improved data processing and web-based tools. Nucleic Acids Res. 2013, 41, D590-D596. [CrossRef]

21. Yilmaz, P.; Parfrey, L.-W.; Yarza, P.; Gerken, J.; Pruesse, E.; Quast, C.; Schweer, T.; Peplies, J.; Ludwig, W.; Glockner, F.O. The SILVA and "All-species Living Tree Project (LTP)" taxonomic frameworks. Nucleic Acid Res. 2014, 42, D643-D648. [CrossRef]

22. Asaf, S.; Numan, M.; Khan, A.L.; Al-Harrasi, A. Sphingomonas: From diversity and genomics to functional role in environmental remediation and plant growth. Crit. Rev. Biotechnol. 2020, 40, 138-152. [CrossRef] 
23. Kurahashi, M.; Fukunaga, Y.; Sakiyama, Y.; Harayama, S.; Yokota, A. Iamia majanohamensis gen. nov., sp. Nov., an actinobacterium isolated from sea cucmber Holothuria edulis, and proposal of Iamiaceae fam. nov. Int. J. Syst. Evol. Microbiol. 2009, 4, 869-873. [CrossRef] [PubMed]

24. Matsumoto, A.; Kasai, H.; Matsuo, Y.; Omura, S.; Shizuri, Y.; Takahashi, Y. Ilumatobacter fluminis gen. nov., sp. nov., a novel actinobacterium isolated from sediment of an estuary. J. Gen. Appl. Microbiol. 2009, 55, 201-205. [CrossRef] [PubMed]

25. Mesa, V.; Gallego, J.L.R.; Gonzáles-Gil, R.; Lauga, B.; Sánchez, J.; Méndez-Garcia, C.; Peláez, A.I. Bacterial, archaeal, and eukaryotic diversity across distinct microhabits in an acid mine drainage. Front. Microbiol. 2018, 8, 1756. [CrossRef]

26. Pankratov, T.A.; Dedysh, S.N. Granulicella gen. nov., sp. nov., Granulicella pectinivorans sp. nov., Granulicella aggregans sp. nov. and Granulicella rose asp. Nov., acidophilic, polymer-degrading acidobacteria from Sphagnum peat bogs. Int. J. Syst. Evol. Microbiol. 2010, 60, 2951-2959. [CrossRef] [PubMed]

27. Cavaletti, L.; Monciardini, P.; Schumann, P.; Rohde, M.; Bamonte, R.; Busti, E.; Sosio, M.; Donadio, S. Actinospica robiniae gen. nov., sp. nov. and Actinospica acidphilia sp. nov.: Proposal for Actinospicaceae fam. nov. and Catenulisporinae subord. nov. in the order Actinomycetales. Int. J. Syst. Evol. Microbiol. 2006, 56, 1747-1753. [CrossRef]

28. Johnson, D.B.; Stallwood, B.; Kimura, S.; Hallberg, K.B. Isolation and characterization of Acidicaldus organivorus, gen. nov., sp. nov.: A novel sulfur-oxidizing, ferric iron-reducing thermos-acidophilic heterotrophic Proteobacterium. Arch. Microbiol. 2006, 185, 212-221. [CrossRef]

29. Kulichevskaya, I.S.; Danilova, O.; Tereshina, V.M.; Kevbrin, V.V. Description of Roseiarcus fermentans gen. Nov., sp. nov., a bacteriochlorophyll a-containing fermentative bacterium related phylogenetically to alphaproteobacterial methanotrophs, and of the family Roseiarcaceae fam. nov. Int. J. Syst. Evol. Microbiol. 2014, 64, 2558-2565. [CrossRef]

30. Antunes, A.; Eder, W.; Fareleira, P.; Santos, H.; Huber, R. Salinisphaera shabanensis gen. nov., sp. nov., a novel, moderately holophilic bacterium from the brine-seawater interface of the Shaban Deep, Red Sea. Extremophiles 2003, 7, 23-94. [CrossRef]

31. Lim, J.-M.; Jeon, C.O.; Lee, J.-C.; Song, S.-M.; Kim, K.-Y.; Kim, C.-J. Marinimicrobium koreense gen. Nov., sp. nov. and Marinimicrobium agarilyticum sp. nov., novelmoderately halotolerant bacteria isolated from tidal flat sediment in Korea. Int. J. Syst. Evol. Microbiol. 2006, 56, 653-657. [CrossRef]

32. Seo, H.-S.; Kwon, K.K.; Yang, S.-H.; Lee, H.-S.; Bae, S.S.; Lee, J.-H.; Kim, S.-J. Marinoscillum gen. nov., a member of the family 'Flexibacteraceae', with Marinoscillum pacificum sp. nov. from a marine sponge and Marinoscillum furvescens nom. Rev., comb. nov. Int. J. Syst. Evol. Microbiol. 2009, 59, 1204-1208. [CrossRef]

33. Nedashkovskaya, O.; Kim, S.B.; Lee, D.H.; Lysenko, A.M.; Shevchenko, L.; Frolova, G.M.; Mikhailov, V.V.; Lee, K.H.; Bae, K.S. Roseivirga ehrenbergii gen. nov., sp. nov., a novel marine bacterium of the phylum 'Bacteroidetes', isolated from the green alga Ulva fenestrata. Int. J. Syst. Evol. Microbiol. 2005, 55, 231-234.

34. Ivanova, E.P.; Nedashkovskaya, O.; Chun, J.; Lysenko, A.M.; Frolova, G.M.; Svetashev, V.I.; Vysotskii, M.V.; Mikhailov, V.V.; Huq, A.; Colwell, R.R. Arenibacter gen. nov., new genus of the family flavobacteriaceae and description of a new species, Arenibacter lactericius sp. nov. Int. J. Syst. Evol. Microbiol. 2001, 51, 1987-1995. [CrossRef] [PubMed]

35. Johansen, J.E.; Nielsen, P.; SjØholm, C. Description of Cellulophaga baltica gen. nov., sp. nov. and Cellulophaga fucicola gen. nov., sp. nov. and reclassification of [Cytophaga] lytica to Cellulophaga lytica gen. nov., comb. nov. Int. J. Syst. Bacteriol. 1999, 49, 1231-1240. [CrossRef]

36. Park, S.; Kim, S.; Jung, Y.-T.; Park, J.-M.; Yoon, J.-H. Confluentibacter lentus gen. nov., sp. nov., isolated from the junction between the ocean and a freshwater lake. Int. J. Syst. Evol. Microbiol. 2016, 66, 868-873. [CrossRef] [PubMed]

37. Jung, S.-Y.; Kang, S.-J.; Lee, M.-H.; Lee, S.-Y.; Oh, T.-K.; Yoon, J.-H. Gaetbulibacter saemankumensis gen. nov., sp. nov., a novel member of family Flavobacteriaceae isolated from a tidal flat sediment in Korea. Int J Syst Evol Microbiol. 2005, 55, 1845-1849. [CrossRef] [PubMed]

38. Nedashkovskaya, O.; Kim, S.B.; Han, S.K.; Lysenko, A.M.; Rohde, M.; Rhee, M.-S.; Frolova, G.M.; Falsen, E.; Mikhailov, V.V.; Bae, K.S. Maribacter gen. nov., a new member of the family Flavobacteriaceae, isolated from marine habits, containing the species Maribacter sedimenticola sp. nov., Maribacter aquivivus sp. nov., Maribacter orientalis sp. nov. and Maribacter ulvicola sp. nov. Int. J. Syst. Evol. Microbiol. 2004, 54, 1017-1023. [CrossRef] [PubMed]

39. Bruns, A.; Rohde, M.; Berthe-Corti, L. Muricauda ruestringensis gen. nov., sp. nov., a facultatively anaerobic, appendaged bacterium from German North Sea intertidal sediment. Int. J. Syst. Evol. Microbiol. 2001, 51, 1997-2006. [CrossRef] [PubMed]

40. Lee, S.D. Tamlana crocina gen. nov., sp. nov., a marine bacterium of the family Flavobacteriaceae, isolated from beach sediment in Korea. Int. J. Syst. Evol. Microbiol. 2007, 57, 764-769. [CrossRef] [PubMed]

41. Urios, L.; Agogué, H.; Lesongeur, F.; Stackebrandt, E.; Lebaron, P. Balneola vulgaris gen. nov., sp. nov., a member of the phylum Bacteroidetes from the north-western Mediterranean Sea. Int. J. Syst. Evol. Microbiol. 2006, 56, 1883-1887. [CrossRef]

42. Wagner-Döbler, I.; Rheims, H.; Felske, A.; Pukall, R.; Tindall, B.J. Jannaschia helgolandesis gen. nov., sp. nov., a novel abundant member of the marine Roseobacter clade from the North Sea. Int. J. Syst. Evol. Microbiol. 2003, 53, 731-738. [CrossRef]

43. Peix, A.; Rivas, R.; Trujillo, M.E.; Vancanneyt, M.; Velázquez, E.; Willems, A. Reclassification of Agrobacterium ferrugineum LMG 128 as Hoeflea marina gen. nov., sp. nov. Int. J. Syst. Evol. Microbiol. 2005, 55, 1163-1166. [CrossRef]

44. Van Trappen, S.; Mergaert, J.; Swings, J. Loktanella salsilacus gen. nov., sp. nov., Loktanella fryxellensis sp. nov. and Loktanella vestfoldensis sp. nov., new member of the RHodobacter group, isolated from microbial mats in Antarctic lakes. Int. J. Syst. Evol. Microbiol. 2004, 54, 1263-1269. [CrossRef] [PubMed] 
45. Yu, Y.; Li, H.-R.; Zeng, Y.-X.; Sun, K.; Chen, B. Pricia antarctica gen. nov., sp. nov., a member of the family Flavobacteriaceae, isolated from Antarctic intertidal sediment. Int. J. Syst. Evol. Microbiol. 2012, 62, 2218-2223. [CrossRef] [PubMed]

46. Bowman, J.P.; Mancuso Nichols, C.; Gibson, J.A.E. Algoriphagus ratkowskyi gen. nov., sp. nov., Brumimicrobium glaciale gen. nov., sp. nov., Cryomorpha ignava gen. nov., sp. nov. and Crocinitomix catalasitica gen. nov., sp. nov., novel flavobacteria isolated from various polar habitats. Int. J. Syst. Evol. Microbiol. 2003, 53, 1343-1355. [CrossRef] [PubMed]

47. Nedashkovskaya, O.I.; Kim, S.B.; Han, S.K.; Rhee, M.-S.; Lysenko, A.; Rhode, M.; Zhukova, N.V.; Frolova, G.M.; Mikhailov, V.V.; Bae, K.S. Algibacter lectus gen. nov., sp. nov., a novel member of the family Flavobacteriaceae isolated from green algae. Int. J. Syst. Evol. Microbiol. 2004, 54, 1257-1261. [CrossRef]

48. Bowman, J.P.; Nichols, D.S. Aequorivita gen. nov., a member of the family Flavobacteriaceae isolated from terrestrial and marine Antarctic habitats. Int. J. Syst. Evol. Microbiol. 2002, 52, 1533-1541.

49. McCammon, S.A.; Bowman, J.P. Taxonomy of Antarctic Flavobacterium species: Description of Flavobacterium gillisiae sp. nov., Flavobacterium tegetincola sp. nov., and Flavobacterium xanthum sp. nov., nom. Rev. And reclassification of [Flavobacterium] salegens as Salegentibacter salegens gen. nov., comb. nov. Int. J. Syst. Evol. Microbiol. 2000, 50, 1055-1063.

50. Bowman, S.A.; Nichols, D.S. Novel members of the family Flavobacteriaceae from Antarctic maritime habits including Subsaximicrobium wynnwilliamsii gen. nov., sp. nov., Subsaximicrobium saxinquilinus sp. nov., Subsaxibacter broadyi gen. nov., sp. nov., and novel species of the Bizionia, Gelidibacter and Gillisia. Int. J. Syst. Evol. Microbiol. 2005, 55, 1471-1486.

51. Liu, C.; Zhang, X.-Y.; Wen, X.-R.; Shi, M.; Chen, X.-L.; Su, H.-N. Arcticiflavibacter luteus gen. nov., sp. nov., a member of the family Flavobacteriaceae isolated from intertidal sand. Int. J. Syst. Evol. Microbiol. 2016, 66, 144-149. [CrossRef] [PubMed]

52. Bowman, J.P.; McCammon, S.A.; Lewis, T.; Skerratt, J.H.; Brown, J.L.; Nichols, D.S.; McMeekin, T.A. Psychroflexus torquis gen. nov., sp. nov., a psychrophilic species from Antarctic sea ice, and reclassification of Flavobacterium gondwanense (Dobson et al. 1993) as Psychroflexus gondwanense gen. nov., comb. nov. Microbiology 1998, 144, 1601-1609. [CrossRef] 